Sławomir Szyller

Warszawa

\title{
Centralny katalog rękopisów średniowiecznych
}

Polskie księgozbiory, w tym zbiory rękopisów, wielokrotnie były rabowane i niszczone: w XVII wieku przez Szwedów, w końcu XVIII i pierwszej połowie XIX wieku - przez Rosjan i wreszcie podczas II wojny światowej - przez Niemców. W wyniku tego część najstarszego dziedzictwa kulturowego Polski została rozproszona, znaczna część - bezpowrotnie zniszczona. Dlatego tym większą wagę należy przykładać do ochrony tych zbiorów, które zachowały się, do ich opracowania, a w pierwszej kolejności - do ich rejestracji.

Szacuje się, że obecnie w polskich zbiorach znajduje się ponad 8000 rękopisów średniowiecznych (do końca XV wieku, ewentualnie do ok. 1520 roku) w ponad 80 bibliotekach $^{1}$. Niewielka tylko ich część doczekała się opisania w opublikowanych katalogach bądź inwentarzach, a z większych bibliotek uczyniły to: Biblioteka Narodowa ${ }^{2}$, Biblioteka Jagiellońska ${ }^{3}$, Biblioteka Uniwersytecka we Wrocławiu ${ }^{4}$, Biblioteka

1 Z. Kozłowska (Handschriftliche Medaevalia in Polen, „Scriptorium” 47:1993, 2, s. 204-226) ocenia liczbę rękopisów średniowiecznych, znajdujących się w 85 instytucjach państwowych, prywatnych i kościelnych, na ok. 7800, przy czym na zbiory kościelne przypada ok. 1400 jednostek. Na podstawie pracy D. Kamolowej Zbiory rękopisów w bibliotekach $i$ muzeach $w$ Polsce, wyd. 2, Warszawa 2003 liczbę rękopisów średniowiecznych w zbiorach publicznych (bez kościelnych) można szacować na ok. 6800 jednostek.

${ }^{2}$ Skrócone opisy wszystkich rękopisów średniowiecznych [w:] Inwentarz rękopisów do potowy XVI wieku w zbiorach Biblioteki Narodowej, oprac. J. Kaliszuk, S. Szyller, Warszawa 2012.

${ }^{3}$ Skrócone opisy całości zbiorów rękopiśmiennych [w:] W. Wisłocki, Katalog rękopisów Biblioteki Uniwersytetu Jagiellońskiego, t. 1-2, Kraków 1877-1881; szczegółowe opisy rękopisów średniowiecznych [w:] Catalogus codicum manuscriptorum medii aevi Latinorum qui in Bibliotheca Jagellonica Cracoviae asservantur, composuerunt S. Włodek, G. Zathey, M. Zwiercan, vol. 1-, Vratislaviae 1980- (ukazało się 10 tomów, obejmujących ponad $50 \%$ zbioru rękopisów średniowiecznych).

${ }^{4}$ Jedynie ok. $10 \%$ wszystkich rękopisów średniowiecznych zostało opisanych w katalogach: Die Handschriften der Staats- und Universitätsbibliothek Breslau, bearb. von 
PAN w Gdańsku ${ }^{5}$, Biblioteka PAN w Kórniku ${ }^{6}$. Ponadto niektóre biblioteki udostępniły w Internecie starsze opisy rękopisów średniowiecznych, jak np. Biblioteka Uniwersytecka we Wrocławiu ${ }^{7}$ czy Biblioteka Uniwersytetu Mikołaja Kopernika w Toruniu ${ }^{8}$. Z mniejszych bibliotek tylko nieliczne posiadają drukowane katalogi obejmujące całość lub część zbiorów rękopiśmiennych ${ }^{9}$. Jednakże znaczna ilość rękopisów średniowiecznych, znajdujących się w małych bibliotekach, nie posiada nie tylko opublikowanych, ale nawet nieopublikowanych opisów i w gruncie rzeczy nie wiadomo dokładnie co zawierają te zbiory.

W sytuacji, gdy zdecydowana większość rękopisów średniowiecznych w Polsce nie posiada pełnych, analitycznych opisów, trudno marzyć o centralnym katalogu zawierającym pełne opisy każdego rękopisu. Ale jest realne, co więcej, niezbędne, sporządzenie centralnego rejestru rękopisów średniowiecznych, obejmującego wszystkie instytucje je posiadające. Dzięki takiemu rejestrowi wiele rękopisów weszłoby do obiegu naukowego, ułatwiony byłby dostęp do tekstów dotąd nieznanych bądź w nieznanych przekazach, możliwe byłoby także przygotowanie projektu szczegółowego opracowania rękopisów dotąd w żaden sposób nieopisanych, zwłaszcza w ośrodkach pozbawionych specjalistów.

Przy założeniu, że projekt zbudowania centralnego katalogu (proponowałbym używać terminu ,inwentarza”, a jeszcze lepiej - „rejestru”) rękopisów średniowiecznych miałby: 1. obejmować wszystkie znane do tej pory zbiory, 2. być zrealizowany w konkretnie oznaczonym czasie, przy realistycznym podejściu zarówno co do kwestii finansowania, jak i zasobów ludzkich, które mogłyby być przy nim wykorzystane - należa-

W. Göber, J. Klapper, Bd. 1, Lief. 1-2, Leipzig 1938-1939; Catalogus manu scriptorum codicum medii aevi Latinorum signa 180-260 comprehendens, Compositus a C.C. Jażdżewski, Wratislaviae 1982; Catalogus codicum medii aevi manuscriptorum qui in Bibliotheca Universitatis Wratislaviensis asservantur signa 6055-6124 comprehendens, composuerunt S. Kądzielski et W. Mrozowicz, Wratislaviae 1998; idem ... signa 6125-6181 comprehendens, composuerunt S. Kądzielski et Jan Przytulski, Wratislaviae 2004.

5 Szczegółowe opisy całości zbioru [w:] Katalog der Danziger Stadtbibliothek, Bd. 5: Die Handschriften der Kirchenbibliothek von St. Marien in Danzig, bearb. von O. Günther, Danzig 1921.

${ }^{6}$ Szczegółowe opisy całości zbioru [w:] J. Zathey, Katalog rękopisów średniowiecznych Biblioteki Kórnickiej, Wrocław 1963.

${ }^{7}$ Wykaz zdigitalizowanych, niedrukowanych katalogów rękopisów (tzw. katalog Friedricha, katalog Göbera, zbiory Thomasa Rehdigera i dawnej Biblioteki Miejskiej) oraz baza zawierająca przybytki po 1945 roku zob. http://www.bu.uni.wroc.pl/oddzialy/piasek/oddzial-rekopisow-zbiory\#katalogi.

${ }^{8}$ Zdigitalizowana kartoteka zawierająca podstawowe informacje o rękopisach średniowiecznych dostępna pod adresem http://www.kat.umk.pl/rekopisy.

${ }^{9}$ Szczegółowe informacje na ten temat podają Z. Kozłowska, dz. cyt., (tylko w zakresie rękopisów średniowiecznych) oraz D. Kamolowa, dz. cyt. 
łoby w pierwszym etapie dość mocno ograniczyć głębokość opisu poszczególnych rękopisów jak i wymagania co do wiarygodności tychże. Chodzi o to, żeby z powodu narzucenia zbyt wysokich wymagań dotyczących obu wspomnianych kwestii nie okazało się w trakcie realizacji projektu, że nie będzie mógł być on zakończony z przyczyn obiektywnych. Dlatego proponowałbym na pierwszym etapie ograniczyć się do opisów bardzo skrótowych i bazujących głównie na opublikowanych i nieopublikowanych katalogach, inwentarzach, kartotekach, bez względu na czas ich powstania, stopień szczegółowości i wiarygodności, a tylko w wypadkach braku jakichkolwiek informacji o konkretnym rękopisie można byłoby sporządzać opisy „,z natury”, również ograniczając się tylko do podstawowych danych. Dopiero po zbudowaniu takiego centralnego rejestru można byłoby, w kolejnych projektach, pogłębiać, uszczegóławiać informacje, zarówno na podstawie istniejących już opracowań, jak i na podstawie wykonywanych specjalnie dla tego projektu opisach szczegółowych.

Sama idea utworzenia centralnego rejestru rękopisów średniowiecznych, w takiej postaci jaką zaproponowałem w zarysie wyżej, jest ze wszech miar pożyteczna, a nawet konieczna. Najpoważniejszym zagrożeniem dla realizacji takiego projektu, poza kwestią finansowania, wydaje się problem osobowy, czyli wykonawców projektu. Nawet bowiem przy założeniu, że pierwszy etap budowy centralnego katalogu rękopisów średniowiecznych ograniczony by został do założenia centralnego rejestru, z bardzo ogólnymi, podstawowymi informacjami, $w$ jego realizacji powinni uczestniczyć specjaliści, osoby o odpowiednim wykształceniu i doświadczeniu, a - niestety - nie jest ich dużo. Ponadto należy wziąć pod uwagę aktualne obciążenie zasadniczą pracą tych osób, które mogłyby wziąć udział w projekcie. Dlatego też przed przystąpieniem do składania wniosku o dofinansowanie projektu należałoby bardzo dokładnie zastanowić się zarówno co do kształtu rejestru, o czym była mowa wyżej, jak i co do możliwości osobowych. 
